\title{
ANALISIS NERACA MASSA DAN SENYAWA KIMIA ASAP CAIR GRADE C MENGGUNAKAN CYCLONE SEPARATOR
}

\section{Mass Balance and Chemical Compound Analysis of Liquid Smoke Grade C Using Cyclone Separator}

\author{
Angky Wahyu Putranto ${ }^{1^{*}}$, Firda Pramesti Puspaningarum ${ }^{2}$, Sukardi ${ }^{2}$ \\ ${ }^{1}$ Jurusan Keteknikan Pertanian - Fakultas Teknologi Pertanian - Universitas Brawijaya \\ Jl. Veteran - Malang 65145 \\ ${ }^{2}$ Jurusan Teknologi Industri Pertanian - Fakultas Teknologi Pertanian - Universitas Brawijaya \\ Jl. Veteran - Malang 65145 \\ *Penulis Korespondensi, email : angkywahyu@ub.ac.id Disubmit:
}

29 Februari 2020 Direvisi: 9 Maret 2020 Diterima: 26 Maret2020

\begin{abstract}
ABSTRAK
Pengolahan limbah tempurung kelapa menjadi arang dan asap cair meningkat pada beberapa tahun terakhir. Asap cair dari limbah tempurung kelapa adalah cairan yang diperoleh dari hasil kondensasi asap residu pada proses pirolisis tempurung kelapa. Asap cair yang dihasilkan dari proses kondensasi pertama disebut sebagai asap cair grade $\mathrm{C}$ yang biasa digunakan sebagai pengawet kayu. Produksi asap cair grade C menggunakan metode kondensasi langsung memiliki rendemen yang rendah serta terdapat campuran abu dan pengotor lain. Oleh karena itu, teknologi cyclone separator digunakan untuk mengatasi masalah tersebut. Namun demikian, diperlukan analisis terkait neraca massa dan senyawa kimia asap cair grade $\mathrm{C}$ menggunakan cyclone separator. Tujuan dari penelitian ini yaitu melakukan analisis neraca massa dan senyawa kimia asap cair grade $\mathrm{C}$ menggunakan cyclone separator. Pada penelitian ini, analisis neraca massa dan senyawa kimia dilakukan pada asap cair yang dihasilkan dengan kondensasi langsung dan dengan teknologi cyclone separator. Hasil analisa neraca massa menunjukkan bahwa teknologi cyclone separator mampu mengurangi zat pengotor mencapai $13 \%$ dari total bahan baku dan meningkatkan 2 kali lipat jumlah asap cair grade $\mathrm{C}$ yang dihasilkan jika dibandingkan dengan kondensasi secara langsung. Sedangkan, analisis senyawa kimia menunjukkan bahwa cyclone separator mampu meningkatkan gugus fungsi senyawa fenolik dan menghilangkan hingga $100 \%$ gugus fungsi senyawa pengotor asap cair seperti karbonil dan asam yang mengandung benzo(a)pyrene.
\end{abstract}

Kata Kunci: Asap Cair Grade C; Cyclone Separator; Neraca Massa; Senyawa Kimia; Tempurung Kelapa

\begin{abstract}
Coconut shell waste processing into charcoal and liquid smoke has increased in recent years. Coconut shell-liquid (CS-LS) is the liquid obtained from the residual smoke condensation results in the pyrolysis process of the coconut shell. Liquid smoke produced from the first condensation process is called as $C$ grade liquid smoke commonly used as a wood preservative. The problem of grade C liquid smoke production by using direct condensation method has a low yield and containing of ash and other impurities. Therefore, the cyclone separator technology is used to overcome this problem. However, it is necessary to analyze the mass balance and chemical compounds of grade C CS-LS using cyclone separator. The study aim is to analyze the mass balance and chemical compound of grade C CS-LS using cyclone separator. In this study, mass balance and chemical compounds analysis were carried out on CS-LS produced by direct condensation and by cyclone separator technology. The results of mass balance analysis show that cyclone separator technology was able to reduce impurities reach $13 \%$ of the total raw materials and increase the amount of $C$ grade liquid
\end{abstract}


smoke produced twice when compared to direct condensation. Meanwhile, the analysis of chemical compounds showed that cyclone separator was able to increase the functional groups of phenolic compounds and eliminate up to $100 \%$ functional groups of liquid smoke impurities such as carbonyl and acid containing benzo(a)pyrene.

Keywords : Grade C Liquid Smoke; Cyclone Separator; Mass Balance; Chemical Compound; Coconut Shell

\section{PENDAHULUAN}

Total produksi tanaman kelapa di Jawa Timur cukup tinggi mencapai 250.654 ton dengan produktivitas sebesar $1.330 \mathrm{~kg} / \mathrm{ha}$ (Direktorat Jendral Perkebunan, 2017). Semakin banyaknya produksi tanaman kelapa, maka jumlah limbah tempurung kelapa yang dihasilkan juga semakin meningkat. Dalam waktu satu hari limbah tempurung kelapa yang dihasilkan dapat mencapai 1.000 butir. Umumnya limbah tersebut hanya dibuang begitu saja tanpa adanya pengolahan lebih lanjut. Padahal limbah tempurung kelapa masih mengandung $14 \%$ selulosa; $46 \%$ lignin; dan 32\% hemiselulosa sehingga dapat dimanfaatkan sebagai bahan baku asap cair (Hasanah et al., 2012).

Asap cair adalah cairan kondensat yang diperoleh melalui proses pirolisis senyawa organik yang mengandung selulosa, hemiselulosa, dan lignin (Kailaku et al., 2016). Proses produksi asap cair dilakukan pada suhu tinggi dan kondisi vakum (Wagiman et al., 2014). Asap cair memiliki 3 tingkatan yaitu grade $\mathrm{A}$, grade $\mathrm{B}$, dan grade $\mathrm{C}$ dengan fungsi yang berbeda pada tiap tingkatan. Asap cair grade $\mathrm{C}$ memiliki warna gelap dengan aroma menyengat. Biasanya asap cair ini digunakan sebagai pengawet kayu, koagulan karet, dan penyerap bau pada kotoran hewan (Kailaku et al., 2016).

Proses pembuatan asap cair grade C secara umum masih menggunakan kondensasi secara langsung setelah asap keluar dari proses pirolisis, sehingga asap cair yang dihasilkan memiliki warna yang gelap. Warna asap cair grade $\mathrm{C}$ yang gelap tersebut memiliki tar dan senyawa pengotor lain seperti benzo(a)pyrene yang cukup tinggi (Putranto et al., 2020). Oleh karena itu diperlukan teknologi untuk memisahkan zat pengotor pada asap hasil pirolisis untuk meningkatkan kualitas dan rendemen asap cair yang dihasilkan.

Teknologi cyclone separator adalah teknologi yang diterapkan untuk memisahkan partikel dari aliran udara, gas atau air tanpa menggunakan filter. Tingkat efisiensi proses pemisahan partikel menggunakan cyclone dapat mencapai $80 \%$ bila dibandingkan dengan teknologi pemisahan lainnya, sehingga teknologi ini banyak digunakan pada proses pemisahan di industri (Marinuc \& Rus, 2011). Teknologi cylone separator juga sangat cocok untuk kondisi suhu dan tekanan tinggi bahkan mencapai tekanan 6 bar dan suhu $400^{\circ} \mathrm{C}$ (Nikhil, 2015). Prinsip utama dari teknologi cyclone separator yaitu memisahkan materi berdasarkan perbedaan berat molekulnya (Taiwo et al., 2016). Namun demikian, analisa terkait perubahan secara fisik dan kimia terhadap penggunaan cyclone separator untuk pembuatan asap cair belum banyak dilakukan. Oleh karena itu, penelitian ini bertujuan untuk menganalisis neraca massa dan senyawa kimia dari asap cair grade $\mathrm{C}$ yang dihasilkan dengan menggunakan tek-nologi cyclone separator.

\section{METODE}

Bahan utama yang digunakan dalam penelitian ini yaitu tempurung kelapa yang telah bersih dan kering. Sedangkan bahan pendukung yang digunakan yaitu LPG dan air untuk proses kondensasi.

Instalasi alat pembuat asap cair pada penelitian ini terdiri dari ruang pirolisis, cyclone separator, tabung kondensasi dan tempat penampungan asap cair grade $\mathrm{C}$, dengan spesifikasi dan desain sesuai pada penelitian Fathussalam, dkk, (2019). Cyclone separator yang digunakan pada penelitian ini memiliki dimensi tinggi $82 \mathrm{~cm}$ dan diameter $20 \mathrm{~cm}$ serta dilengkapi centrifugal blower dengan daya hisap $280 \mathrm{CMH}$. Selain itu, alat lain yang digunakan yaitu kompor gas dan regulator merk Winn Gas W181NMHP, pompa air, selang air, dan GC-MS tipe HP-6890 untuk proses analisa senyawa kimia. 


\section{Proses Pembuatan Asap Cair Grade C}

Pada penelitian ini proses pembuatan asap cair grade $\mathrm{C}$ dilakukan dengan dua metode yang berbeda. Selanjutnya, asap cair dihitung neraca massa dan dianalisis senyawa kimia untuk masing-masing metode tersebut. Metode pembuatan asap cair grade C yang pertama dilakukan seperti pada penelitian Putranto et al., (2020), dimana asap yang dihasilkan dari proses pirolisis diteruskan secara langsung menuju tabung kondensasi untuk menghasilkan asap cair grade C. Sedangkan metode kedua yaitu asap dari proses pirolisis dilewatkan pada cyclone separator dan diteruskan ke tabung kondensasi yang selanjutnya menghasilkan asap cair grade C.

Diagram alir perbedaan metode pembuatan asap cair grade $\mathrm{C}$ dapat dilihat pada Gambar 1. Bahan baku tempurung kelapa kering yang digunakan untuk kedua metode yaitu sebesar $3000 \mathrm{Kg}$. Tempurung kelapa kering selanjutnya dimasukkan ke dalam ruang pirolisis dengan kapasitas 3,75 ton dan dilakukan proses pengarangan (pirolisis). Proses pirolisis dilakukan pada suhu 300$400^{\circ} \mathrm{C}$ sampai semua input bahan terkonversi menjadi arang. Waktu pirolisis agar bahan baku menjadi arang secara keseluruhan dengan metode kondensasi langsung dilakukan selama 120 jam, sedangkan metode cyclone separator dilakukan proses pirolisis selama 48 jam.

\section{Prosedur Analisa}

Prosedur analisa neraca massa dilakukan dengan memantau secara langsung dan menghitung nilai input-output pada setiap proses produksi asap cair grade C, baik metode kondensasi langsung maupun dengan meggunakan teknologi cyclone separator. Sedangkan identifikasi senyawa kimia asap cair grade $\mathrm{C}$, dilakukan menggunakan GCMS yang kemudian dianalisa dan digolongkan berdasarkan gugus fungsi senyawa yang terdeteksi.

\section{HASIL DAN PEMBAHASAN}

\section{Analisis Neraca Massa Asap Cair Grade C dari Kondensasi Langsung}

Neraca massa asap cair yang diproduksi secara kondensasi langsung dapat dilihat pada Gambar 2. Rincian perhitungan neraca massa proses pirolisis dapat dilihat pada Tabel 1, sedangkan rincian perhitungan neraca massa proses kondensasi asap cair dari kondensasi langsung dapat dilihat pada Tabel 2.

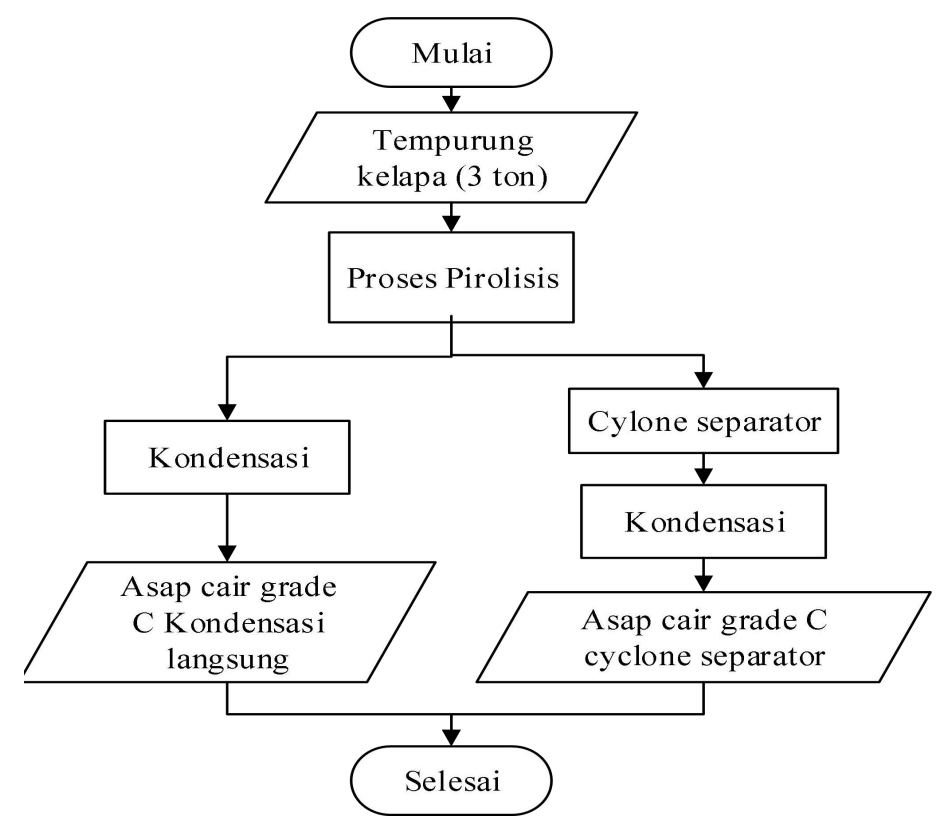

Gambar 1. Diagram alir proses pembuatan asap cair grade c 


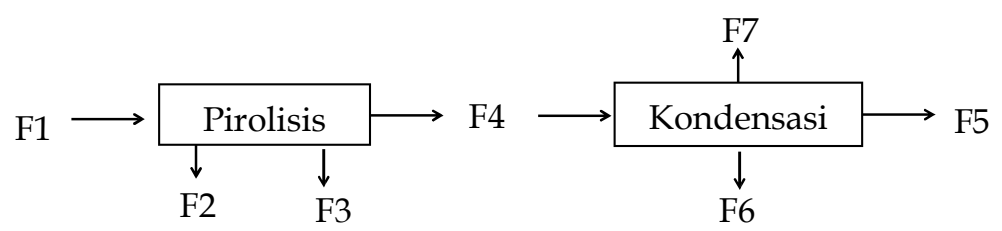

Gambar 2. Neraca massa produksi asap cair grade c dengan metode kondensasi langsung

Berdasarkan Gambar 2, dapat diketahui bahwa input yang digunakan dalam proses pirolisis berupa tempurung kelapa kering sebanyak $3.000 \mathrm{~kg}$ (F1). Setelah dilakukan proses pirolisis 72 jam, terdapat 3 jenis output. Output pertama berupa arang kasar sebanyak $1.000 \mathrm{~kg}$ (F2), output kedua yaitu abu sebanyak $2 \mathrm{~kg}$ (F3) dan output lain berupa asap panas terdiri dari $\mathrm{CO}_{2}$ sebesar $1.128 \mathrm{~kg}$, $\mathrm{O}_{2}$ sebesar $742 \mathrm{~kg}, \mathrm{H}_{2} \mathrm{O}$ sebesar $124 \mathrm{~kg}$ dan $\mathrm{N}_{2}$ sebesar $4 \mathrm{~kg}$ (F4) (Tabel 1). Asap panas hasil pirolisis tersebut, dilanjutkan dengan proses kondensasi. Proses kondensasi dilakukan pada suhu ruang $\left(25-28^{\circ} \mathrm{C}\right)$ dan menghasilkan 3 jenis output.

Output pertama berupa asap cair grade C sebanyak 50,5 kg (F5), output kedua yaitu abu sebanyak 1,95 kg (F6) dan output lain berupa asap panas yang terdiri dari $\mathrm{CO}_{2}$ sebesar $1.098,39 \mathrm{~kg}, \mathrm{O}_{2}$ sebesar $722,52 \mathrm{~kg}$, $\mathrm{H}_{2} \mathrm{O}$ sebesar $120,74 \mathrm{~kg}$ dan $\mathrm{N}_{2}$ sebesar $3,90 \mathrm{~kg}$ (F7) (Tabel 2). Pada proses fast pyrolysis (proses pirolisis dengan suhu tinggi dalam keadaan kedap oksigen) dengan input berupa bahan organik yang mengandung selulosa, hemiselulosa, dan lignin, akan menghasilkan beberapa output seperti uap, aerosol, dan arang. Massa uap yang dihasilkan selama proses fast pyrolysis yaitu mengandung gas $\mathrm{CO}_{2}$ sebesar $56,4 \% ; \mathrm{O}_{2}$ sebesar $37,1 \% ; \mathrm{H}_{2} \mathrm{O}$ sebesar $6,2 \%$; dan $\mathrm{N}_{2}$ sebesar 0,2\% dan abu sebesar 0,1\% (Bridgwater, et al., 1999). Oleh karena itu perhitungan massa komponen uap yang dihasilkan dari pirolisis tempurung kelapa pada penelitian ini, berdasarkan persentase setiap komponen uap yang dihasilkan dari proses fast pyrolysis.

Tabel 1. Neraca massa proses pirolisis asap cair grade c (kondensasi langsung)

\begin{tabular}{lcccc}
\hline \multirow{2}{*}{ Komponen } & Alur Masuk & \multicolumn{3}{c}{ Alur Keluar } \\
\cline { 2 - 5 } & F1 (kg) & F2 (kg) & F3 (kg) & F4 (kg) \\
\hline Tempurung kelapa & 3.000 & - & - & - \\
Arang kasar & - & 1.000 & - & - \\
$\mathrm{Abu}$ & - & - & 2 & - \\
$\mathrm{CO}_{2}$ & - & - & - & 1.128 \\
$\mathrm{O}_{2}$ & - & - & - & 742 \\
$\mathrm{H}_{2} \mathrm{O}$ & - & - & - & 124 \\
$\mathrm{~N}_{2}$ & - & - & - & 2 \\
\hline \multicolumn{2}{r}{} & 3.000 & 1.000 & 3.000 \\
\hline
\end{tabular}

Tabel 2. Neraca massa proses kondensasi asap cair grade c (kondensasi langsung)

\begin{tabular}{|c|c|c|c|c|}
\hline \multirow{2}{*}{ Komponen } & \multirow{2}{*}{$\begin{array}{c}\text { Alur Masuk } \\
\text { F4 (kg) } \\
\end{array}$} & \multicolumn{3}{|c|}{ Alur Keluar } \\
\hline & & F5 (kg) & F6 (kg) & F7 (kg) \\
\hline $\mathrm{CO}_{2}$ & 1.128 & - & - & $1.098,39$ \\
\hline $\mathrm{O}_{2}$ & 742 & - & - & 722,52 \\
\hline $\mathrm{H}_{2} \mathrm{O}$ & 124 & - & - & 120,74 \\
\hline $\mathrm{N}_{2}$ & 4 & - & - & 3,90 \\
\hline Asap Cair Grade C & - & 50,5 & - & - \\
\hline Abu & - & - & 1,95 & - \\
\hline Subtotal & 1.998 & 50,5 & 1,95 & $1.945,55$ \\
\hline Total & 1.998 & \multicolumn{3}{|c|}{1.998} \\
\hline
\end{tabular}


Neraca Massa Asap Cair Grade C Menggunakan Cyclone separator

Neraca massa asap cair yang diproduksi menggunakan teknologi cyclone separator dapat dilihat pada Gambar 3. Rincian perhitungan setiap aliran massa proses pirolisis asap cair menggunakan teknologi cyclone separator dapat dilihat pada Tabel 3. Rincian aliran massa proses filtrasi pada cyclone separator dapat dilihat pada Tabel 4 . Sedangkan rincian neraca massa proses kondensasi asap cair menggunakan teknologi cyclone separator dapat dilihat pada Tabel 5 .
Berdasarkan Gambar 3, dapat diketahui bahwa bahan baku yang digunakan dalam proses pirolisis berupa tempurung kelapa kering sebanyak $3.000 \mathrm{~kg}$ (F1). Setelah dilakukan proses pirolisis selama 48 jam, terdapat 4 jenis output (Tabel 3). Output pertama berupa arang kasar sebanyak 1.000 $\mathrm{kg}$ (F2). Output kedua berupa arang halus sebanyak $350 \mathrm{~kg}$ (F3). Output ketiga yaitu abu sebanyak 1,65 kg (F4). Output lain berupa asap panas kotor terdiri dari $\mathrm{CO}_{2}$ sebesar 930,6 kg; $\mathrm{O}_{2}$ sebesar $612,15 \mathrm{~kg} ; \mathrm{H}_{2} \mathrm{O}$ sebesar 102,3 kg; dan $\mathrm{N}_{2}$ sebesar 3,3 kg (F5).

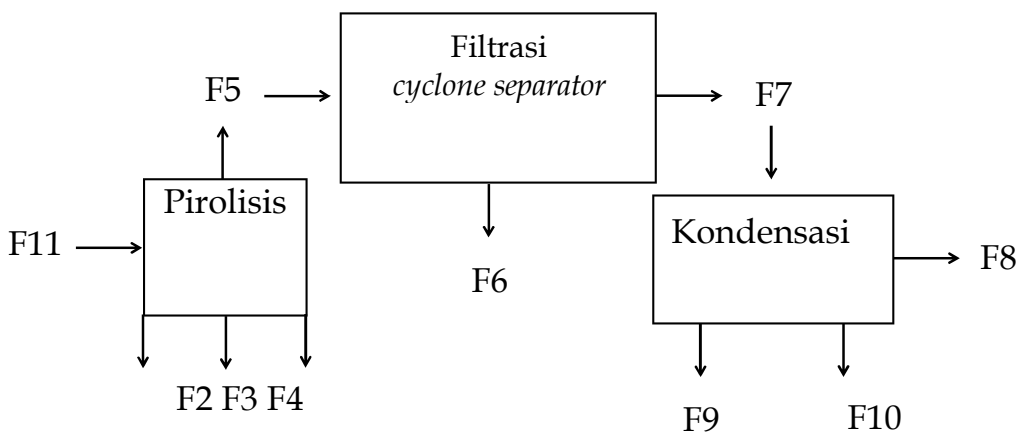

Gambar 3. Neraca Massa Produksi Asap Cair Grade C Cyclone separator

Tabel 3. Neraca massa proses pirolisis asap cair grade c cyclone separator

\begin{tabular}{|c|c|c|c|c|c|}
\hline \multirow{2}{*}{ Komponen } & \multirow{2}{*}{$\begin{array}{c}\text { Alur Masuk } \\
\text { F1 (kg) }\end{array}$} & \multicolumn{4}{|c|}{ Alur Keluar } \\
\hline & & F2 (kg) & F3 (kg) & F4 (kg) & F5 (kg) \\
\hline Tempurung & 3.000 & - & - & - & - \\
\hline \multicolumn{6}{|l|}{ kelapa } \\
\hline Arang kasar & - & 1.000 & - & - & - \\
\hline Arang halus & - & - & 350 & - & - \\
\hline $\mathrm{Abu}$ & - & - & - & 1,65 & - \\
\hline $\mathrm{CO}_{2}$ & - & - & - & - & 930,6 \\
\hline $\mathrm{O}_{2}$ & - & - & - & - & 612,15 \\
\hline $\mathrm{H}_{2} \mathrm{O}$ & - & - & - & - & 102,3 \\
\hline $\mathrm{N}_{2}$ & - & - & - & - & 3,3 \\
\hline Subtotal & 3.000 & 1.000 & 350 & 1,65 & $1.648,35$ \\
\hline Total & 3.000 & & & 00 & \\
\hline
\end{tabular}

Tabel 4. Neraca massa proses filtrasi pada cyclone separator

\begin{tabular}{|c|c|c|c|}
\hline \multirow{2}{*}{ Komponen } & \multirow{2}{*}{$\begin{array}{c}\text { Alur Masuk } \\
\text { F5 (kg) }\end{array}$} & \multicolumn{2}{|c|}{ Alur Keluar } \\
\hline & & F6 (kg) & F7 (kg) \\
\hline $\mathrm{CO}_{2}$ & 930,6 & - & 709,71 \\
\hline $\mathrm{O}_{2}$ & 612,15 & - & 466,85 \\
\hline $\mathrm{H}_{2} \mathrm{O}$ & 102,3 & - & 78,02 \\
\hline $\mathrm{N}_{2}$ & 3,3 & - & 2,52 \\
\hline Komponen pengotor & - & 391,25 & - \\
\hline Subtotal & $1.648,35$ & 391,25 & $1.257,10$ \\
\hline Total & $1.648,35$ & & \\
\hline
\end{tabular}


Tabel 5. Neraca Massa Proses Kondensasi Asap Cair Grade C Cyclone separator

\begin{tabular}{lcccc}
\hline \multirow{2}{*}{ Komponen } & Alur Masuk & \multicolumn{3}{c}{ Alur Keluar } \\
\cline { 2 - 5 } & F7 (kg) & F8 (kg) & F9 (kg) & F10 (kg) \\
\hline $\mathrm{CO}_{2}$ & 709,71 & - & - & 652,04 \\
$\mathrm{O}_{2}$ & 466,85 & - & - & 428,91 \\
$\mathrm{H}_{2} \mathrm{O}$ & 78,02 & - & - & 71,68 \\
$\mathrm{~N}_{2}$ & 2,52 & - & - & 2,31 \\
$\mathrm{Asap}$ Cair Grade C & - & 101 & - & - \\
$\mathrm{Abu}$ & - & - & 1,16 & - \\
\hline \multicolumn{1}{c}{ Subtotal } & $1.257,10$ & 101 & 1,16 & $1.154,94$ \\
\hline \multicolumn{1}{c}{ Total } & $1.257,10$ & \multicolumn{3}{c}{$1.257,10$} \\
\hline
\end{tabular}

Asap panas yang keluar dari proses pirolisis tersebut, dilanjutkan dengan proses filtrasi menggunakan teknologi cyclone separator dan menghasilkan 2 jenis output (Tabel 4). Output pertama berupa komponen pengotor sebanyak 391,25 kg (F6). Output kedua yaitu asap panas (F7) yang terdiri dari $\mathrm{CO}_{2}$ sebesar 709,71 kg; $\mathrm{O}_{2}$ sebesar 466,85 kg; $\mathrm{H}_{2} \mathrm{O}$ sebesar 78,02 kg; dan $\mathrm{N}_{2}$ sebesar 2,52 kg. Asap panas yang keluar dari cyclone separator kemudian diteruskan ke proses kondensasi. Proses kondensasi dilakukan pada suhu ruang dan menghasilkan 3 jenis output. Output pertama berupa asap cair grade C sebanyak $101 \mathrm{~kg}$ (F8). Output kedua yaitu abu sebanyak 1,16 kg (F9). Output lain berupa asap panas terdiri dari $\mathrm{CO}_{2}$ sebesar $652,04 \mathrm{~kg} ; \mathrm{O}_{2}$ sebesar 428,91 kg; $\mathrm{H}_{2} \mathrm{O}$ sebesar $71,68 \mathrm{~kg}$; dan $\mathrm{N}_{2}$ sebesar 2,31 kg (F10) (Tabel 5)

Proses pirolisis menggunakan cyclone separator tidak hanya menghasilkan arang kasar tetapi juga menghasilkan arang halus sebanyak $350 \mathrm{~kg}$ (Tabel 3) yang terdapat pada tangki pirolisis. Semakin banyak arang yang dihasilkan maka proses pirolisis semakin baik. Selain itu, abu yang dihasilkan pada proses pirolisis menggunakan cyclone separator juga lebih rendah $(1,65 \mathrm{~kg})$ jika dibandingkan dengan abu pada pirolisis dengan kondensasi secara langsung yaitu sebesar $2 \mathrm{~kg}$. Abu adalah zat sisa hasil pembakaran zat organik, dimana jumlah abu yang rendah sangat diinginkan pada proses pirolisis. Pada umunya untuk menurunkan kadar abu pada proses pirolisis bahan organik, dilakukan dengan meningkatkan suhu pirolisis, namun pada penelitian ini jumlah abu yang dihasilkan dapat diturunkan pada suhu pirolisis yang sama dengan adanya cylone separator.
Di sisi lain, asap cair grade $\mathrm{C}$ yang dihasilkan dengan penyaringan menggunakan cyclone separator ini memiliki jumlah asap cair lebih banyak jika dibandingkan dengan jumlah asap cair grade $\mathrm{C}$ yang dihasilkan melalui kondensasi langsung yaitu dari 50,5 kg menjadi $101 \mathrm{~kg}$. Peningkatan jumlah asap cair grade $\mathrm{C}$ yang dihasilkan disebabkan karena beberapa zat pengotor yang terbawa oleh asap hasil pirolisis atau partikel pengotor yang terikut di dalam gas $\mathrm{H}_{2}, \mathrm{CO}_{2}$ dan $\mathrm{N}_{2}$ dapat dikurangi hingga 391,25 kg (Tabel 4). Prinsip kerja teknologi cyclone separator yaitu memanfaatkan gaya sentrifugal dan gaya gravitasi untuk memisahkan partikel dari aliran gas (Marinuc \& Rus, 2011). Aliran gas dari ruang pirolisis masuk dari bagian samping cyclone separator dengan bantuan centrifugal blower dengan air flow sebesar 280 Cubic Meter per Hour (CMH) menggunakan prinsip gaya sentrifugal. Adanya gaya sentrifugal ini, partikel padat akan dilemparkan ke dinding siklon, dimana partikel tersebut akan kehilangan energi dan jatuh bergerak ke bawah dengan bantuan gaya gravitasi. Hal ini dapat terjadi karena massa padatan lebih besar daripada massa gas. Sedangkan aliran gas yang telah disaring selanjutnya menuju ke pipa bagian atas untuk dialirkan pada tangki kondensasi.

Gas dari proses pirolisis yang memiliki sedikit partikel pengotor, akan lebih mudah untuk dapat dirubah fasenya menjadi bentuk cair pada proses kondensasi, sehing-ga asap cair yang dihasilkan juga memiliki volume yang tinggi. Selain itu, peningkatan hasil asap cair juga dipengaruhi oleh kadar air bahan dan proses kondensasi (Budaraga et al., 2016). Proses kondensasi yang optimal akan menghasilkan rendemen dan kualitas asap cair yang baik. Pada penelitian ini asap cair grade $\mathrm{C}$ yang dihasilkan dengan cyclone 
separator sebelumnya dilewatkan pada tabung kondensasi yang dirancang oleh Fathussalam, dkk (2019), yaitu memiliki kapasitas 70 liter air sebagai media pendingin dan dilengkapi dengan pompa air yang dapat mengalirkan debit air 3000L/jam. Tabung kondensasi juga dilengkapi pipa spiral dari stainless stell dengan panjang $14 \mathrm{~m}$ untuk meningkatkan kontak udara panas dengan media pendingin. Semakin cepat pergerakan media pendingin, maka gas yang akan dikondensasi juga lebih cepat berubah dalam fase cair. Sebaliknya jika media pendingin tidak cepat merubah fase gas, maka gas tersebut lebih mudah mengalami penguapan, sehingga rendemen asap cair menjadi rendah pula (Nasruddin, 2015).

Analisis Senyawa Kimia Asap Cair Grade C Hasil analisis senyawa kimia menggunakan GC-MS terhadap asap cair yang diperoleh dengan kondensasi langsung dan asap cair yang diproduksi menggunakan teknologi cyclone separator memiliki perbedaan yang cukup signifikan yang dapat dilihat dari gugus fungsi senyawa yang dapat dikelompokkan menjadi senyawa fenol, karbonil, ester, sikloalken, alcohol, alkoksi dan asam seperti yang ditunjukkan pada Tabel 6. Hal ini juga sesuai dengan penelitian Hadanu \& Daniel (2016) yang menyatakan bahwa, senyawa dalam asap cair terbagi menjadi tiga gugus fungsi dominan diantaranya yaitu: asam karboksilat, fenol, dan karbonil. Selain tiga gugus fungsi tersebut, terdapat beberapa gugus fungsi lain seperti: alkohol, lakton, dan hidrokarbon.

Berdasarkan pengelompokan gugus fungsi senyawa pada Tabel 6, terdapat beberapa gugus fungsi senyawa yang dominan pada kedua jenis asap cair grade C, yaitu senyawa fenol. Gugus fungsi fenol merupakan komponen dominan dalam asap cair yang dihasilkan dari proses pirolisis lignin pada tempurung kelapa pada suhu $300^{\circ} \mathrm{C}$ (Budaraga et al., 2016). Fenol memiliki peranan yang penting dalam menciptakan cita rasa pada asap cair (Montazeri et al., 2013). Selain itu, asap cair dengan kandungan fenol yang cukup tinggi, membuat asap cair tersebut memiliki sifat sebagai antimikroba dan antioksidan (Kailaku et al., 2017), sehingga sangat cocok diaplikasikan pada produk pangan sebagai pengawet alami.

Berdasarkan Tabel 6, asap cair yang dihasilkan dengan proses kondensasi langsung memiliki 11 senyawa yang masuk dalam gugus fungsi fenolik, 4 senyawa karbonil, 9 senyawa alkoksi, masing-masing 1 senyawa ester, sikloalken dan alkohol, serta 4 senyawa asam benzoat. Sedangkan pada asap cair yang dihasilkan dengan menggunakan cyclone separator memiliki 17 senyawa fenolik, 10 senyawa alkoksi, 3 senyawa sikolalken dan 1 senyawa yang masuk ke dalam gugus senyawa alkoholik. Hal tersebut menunjukkan bahwa asap cair yang menggunakan cyclone separator memiliki gugus senyawa fenol dan alkoksi lebih banyak jika dibandingkan dengan asap cair yang dihasilkan secara kondensasi langsung. Hal ini juga sesuai dengan Hadanu \& Apituley (2016), bahwa asap cair yang diperoleh dari reaksi degradasi termal selulosa, hemiselulosa, dan lignin tempurung kelapa pada suhu $350-420^{\circ} \mathrm{C}$ menghasilkan 19 senyawa turunan fenol, dimana 14 senyawa tergolong dalam gugus fungsi fenol dan 10 gugus fungsi alkoksi. Kelompok fungsional dari konstituen utama dan minor dari asap cair dari tempurung kelapa dapat diklasifikasikan ke dalam beberapa gugus senyawa fungsional yaitu $90,75 \%$ fenol, $38,50 \%$ alkohol, $36,70 \%$ alkoksi, 5,66\% karbonil, 3,71\% sikloalken, dan 1,81\% kelompok fungsional furan (Hadanu \& Apituley, 2016).

Beberapa gugus fungsi senyawa penyusun asap cair yang dapat dideteksi, juga tidak terlepas dari komponen utama tempurung kelapa yaitu lignin, hemiselulosa dan selulosa. Pirolisis lignin pada suhu $300-500^{\circ} \mathrm{C}$ akan menjadi sumber utama senyawa fenol (Budaraga et al., 2016), pirolisis hemiselulosa akan menghasilkan senyawa furan, turunan furan, dan serangkaian asam karboksilat alifatik (Sisko et al., 2007). Di sisi lain pertukaran senyawa alifatik selulosa pada suhu tinggi atau dengan degradasi termal hemiselulosa juga akan menghasilkan senyawa fenol (Darmadji \& Triyudiana, 2006). Sedangkan pirolisis selulosa dan hemiselulosa adalah sumber utama karbonil dan asam karboksilat (Hadanu \& Apituley, 2016). 
Tabel 6. Penggolongan Gugus Fungsi Senyawa Asap Cair Grade C

\begin{tabular}{|c|c|c|c|c|c|c|c|c|}
\hline \multirow{2}{*}{$\begin{array}{c}\text { Asap Cair } \\
\text { Grade C }\end{array}$} & \multirow[t]{2}{*}{ Senyawa } & \multicolumn{7}{|c|}{$\begin{array}{c}\text { Gugus Fungsi Asap Cair } \\
\text { Grade C }\end{array}$} \\
\hline & & $\mathbf{a}$ & $\mathbf{b}$ & c & d & e & $\mathbf{f}$ & $\mathrm{g}$ \\
\hline \multirow{21}{*}{$\begin{array}{l}\text { Kondensasi } \\
\text { Langsung }\end{array}$} & Phenol & $\sqrt{ }$ & & & & & & \\
\hline & 3-Hexene, 3,4-dimethyl & & $\sqrt{ }$ & & & & & \\
\hline & Phenol, 2-methyl & $\sqrt{ }$ & & & & & & \\
\hline & Phenol, 4-methyl & $\sqrt{ }$ & & & & & & \\
\hline & 2,3-Dimethyl-2-cyclopenten-1-one & & & & $\sqrt{ }$ & & & \\
\hline & Phenol, 2-methoxy & $\sqrt{ }$ & & & & & $\sqrt{ }$ & \\
\hline & Phenol, 2,3-dimethyl & $\sqrt{ }$ & & & & & & \\
\hline & Phenol, 3-ethyl & $\sqrt{ }$ & & & & & & \\
\hline & 2,5-Xylenol & $\sqrt{ }$ & & & & & & \\
\hline & Phenol, 2-methoxy-4-methyl & $\sqrt{ }$ & & & & & $\sqrt{ }$ & \\
\hline & Phenol, 4-ethyl-2-methoxy & $\sqrt{ }$ & & & & & $\sqrt{ }$ & \\
\hline & Phenol, 2,6-dimethoxy & $\sqrt{ }$ & & & & & $\sqrt{ }$ & \\
\hline & Vanillin & & & $\sqrt{ }$ & & & & \\
\hline & Benzoic acid, 2,5 & & & & & & & $\sqrt{ }$ \\
\hline & Benzoic acid, 2,4 & & & & & & & $\sqrt{ }$ \\
\hline & 3-Hydroxy-4-methoxybenzoic acid & & $\sqrt{ }$ & & & & $\sqrt{ }$ & $\sqrt{ }$ \\
\hline & Ethanone, 1-(4-hydroxy-3-methoxyphenyl) & & $\sqrt{ }$ & & & $\sqrt{ }$ & $\sqrt{ }$ & \\
\hline & Benzoic acid, 4-hydroxy-3-methoxy & & $\sqrt{ }$ & & & & $\sqrt{ }$ & $\sqrt{ }$ \\
\hline & 2,3,5-Trimethoxytoluene & & & & & & $\sqrt{ }$ & \\
\hline & Phenol, 2,6-dimethoxy-4-(2-propenyl) & $\sqrt{ }$ & & & & & $\sqrt{ }$ & \\
\hline & Jumlah & 11 & 4 & 1 & 1 & 1 & 9 & 4 \\
\hline \multirow{21}{*}{$\begin{array}{l}\text { Cyclone } \\
\text { separator }\end{array}$} & Phenol & $\sqrt{ }$ & & & & & & \\
\hline & 4,4-Dimethyl-2-cyclopenten-1-one & & & & $\sqrt{ }$ & & & \\
\hline & 2-Cyclopenten-1-one, 2,3-dimethyl & & & & $\sqrt{ }$ & & & \\
\hline & Phenol, 2-methyl & $\sqrt{ }$ & & & & & & \\
\hline & Phenol, 4-methyl & $\sqrt{ }$ & & & & & & \\
\hline & Phenol, 2-methoxy & $\sqrt{ }$ & & & & & $\sqrt{ }$ & \\
\hline & Phenol, 2,6-dimethyl & $\sqrt{ }$ & & & & & & \\
\hline & 2-Cyclopenten-1-one, 3-ethyl-2-hydroxy & $\sqrt{ }$ & & & $\sqrt{ }$ & & & \\
\hline & Phenol, 2,4-dimethyl & $\sqrt{ }$ & & & & & & \\
\hline & Phenol, 3-ethyl & $\sqrt{ }$ & & & & & & \\
\hline & Phenol, 2-methoxy-3-methyl & $\sqrt{ }$ & & & & & $\sqrt{ }$ & \\
\hline & Phenol, 4-methoxy-3-methyl & $\sqrt{ }$ & & & & & $\sqrt{ }$ & \\
\hline & Phenol, 2-methoxy-4-methyl & $\sqrt{ }$ & & & & & $\sqrt{ }$ & \\
\hline & Phenol, 4-ethyl-2-methoxy & $\sqrt{ }$ & & & & & $\sqrt{ }$ & \\
\hline & Phenol, 2,6-dimethoxy & $\sqrt{ }$ & & & & & $\sqrt{ }$ & \\
\hline & 2H-Pyran-2,4(3H)-dione, 3-acetyl-6-methyl & & & & & $\sqrt{ }$ & & \\
\hline & Phenol, 2-methoxy-4-(1-propenyl)-,(E) & $\sqrt{ }$ & & & & & $\sqrt{ }$ & \\
\hline & $\begin{array}{l}\text { 2,3,5-Trimethoxytoluene Benzene, 1,2,5- } \\
\text { trimethoxy-3-methyl }\end{array}$ & $\sqrt{ }$ & & & & & $\sqrt{ }$ & \\
\hline & 2-Methoxy-4-propyl-phenol & $\sqrt{ }$ & & & & & $\sqrt{ }$ & \\
\hline & Phenol, 2,6-dimethoxy-4-(2-propenyl) & $\sqrt{ }$ & & & & & $\sqrt{ }$ & \\
\hline & Jumlah & 17 & 0 & 0 & 3 & 1 & 10 & 0 \\
\hline
\end{tabular}

Keterangan : a : Fenol, b: Karbonil, c : Ester, d : Sikloalken, e : Alkohol, f : Alkoksi, g : Asam

Selain itu, berdasarkan Tabel 6, senyawa karbonil, ester dan asam juga tidak teridentifikasi dalam asap cair yang dihasilkan dari cyclone separator. Beberapa senyawa yang tergolong dalam gugus fungsi asam seperti asam benzoat seperti benzoic acid, 2,4, senyawa benzoic acid, 2,5; 3-Hydroxy-4methoxybenzoic acid dan benzoic acid, 4hydroxy-3-methoxy merupakan senyawa yang tergolong dalam benzo(a)pyrene. Senyawa benzo(a)pyrene ini merupakan salah satu senyawa yang mendominasi dari 
senyawa pengotor pada asap cair selain senyawa tar (Budaraga et al., 2017). Terpisahnya zat pengotor yang didalamnya termasuk senyawa benzo(a)pyrene menggunakan cyclone separator selain dibuktikan secara fisik dari perhitungan neraca massa, juga didukung dengan tidak adanya gugus fungsi senyawa asam sebagai senyawa pengotor seperti yang ditunjukkan pada Tabel 6.

Selain itu, adanya senyawa pengotor yang banyak terikut pada asap pirolisis juga lebih mudah menempel pada dinding tabung kondensor. Semakin banyak partikel pengotor yang menempel pada dinding kondensor, maka akan menghasilkan kerak yang susah dihilangkan. Sebagai dampaknya, proses kondensasi menjadi tidak maksimal akibat kontak asap dengan media pendingin semakin sedikit, sehingga menyebabkan senyawa fenol dan rendemen asap cair yang dihasilkan juga semakin menjadi rendah. Keberadaan senyawa benzo(a)pyrene selain menyebabkan jumlah asap cair menjadi rendah, namun juga merupakan senyawa karsinogenik alami yang sangat berbahaya jika digunakan sebagai pengawet makanan. Oleh karena itu diperlukan beberapa usaha untuk menghilangkan senyawa pengotor tersebut melalui penerapan suhu pirolisis yang lebih tinggi (Budaraga et al., 2016) dan melakukan filtrasi asap cair menggunakan arang aktif dan zeolit (Budaraga et al., 2017).

Namun demikian, asap hasil pirolisis yang masih memiliki kadar tar, abu dan pengotor lain akan tetap terikut walaupun fase asap sudah berubah dalam bentuk cair. Hal tersebut akan berdampak terhadap penurunan jumlah asap cair dan kualitas senyawa kimia yang dihasilkan. Oleh karena itu, proses pemisahan senyawa pengotor asap cair pada fase gas atau sebelum proses kondensasi menjadi hal yang perlu dipertimbangkan yang selanjutnya dapat dikombinasikan dengan filtrasi arang aktif dan zeolit (pemisahan pada fase cair) untuk meningkatkan kuantitas dan kualitas asap cair yang dihasilkan.

\section{Kenampakan Asap Cair yang Dihasilkan}

Kenampakan secara visual hasil asap cair yang diproduksi dengan kondensasi langsung dan asap cair yang diproduksi menggunakan teknologi cyclone separator dapat dilihat pada Gambar 4.

Apabila dilihat dari kenampakan secara visual, warna asap cair grade $\mathrm{C}$ yang dihasilkan dari proses kondensasi langsung cenderung memiliki warna coklat gelap (Gambar 4b). Warna coklat gelap pada asap cair ini disebabkan karena adanya senyawa karbonil pada asap cair. Semakin banyak senyawa karbonil pada asap cair, maka warna asap cair akan semakin gelap. Hal ini juga sejalan dengan Budaraga et al., (2016), bahwa asap cair dari tempurung kelapa memiliki warna coklat kehitaman karena banyaknya senyawa karbonil di dalamnya.

Sedangkan asap cair yang diproduksi menggunakan teknologi cyclone separator yaitu memiliki warna kuning keruh. Hal tersebut menandakan bahwa senyawa pengotor dan karbonil sudah tidak terdapat pada asap cair dengan menggunakan cyclone separator. Seperti yang ditunjukkan pada Tabel 6. bahwa, cyclone separator mampu mengurangi 4 senyawa karbonil pada asap cair grade C. Warna kuning keruh pada asap cair yang diperoleh menggunakan cyclone separator tersebut juga sesuai dengan standar mutu asap cair dari Jepang, dimana asap cair memiliki warna kuning keruh atau coklat kemerahan dan transparan (Yatagai, 2002).

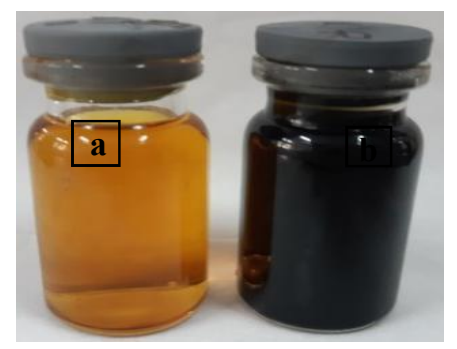

Gambar 4. Perbedaan penampakan hasil asap cair grade c. dengan metode cyclone separator (a) dan dengan kondsensasi langsung (b) 
Selain itu, perbedaan kenampakan visual kedua jenis asap cair tersebut juga dipengaruhi oleh jumlah kandungan tar dan pengotor didalamnya. Walaupun pada penelitian ini kandungan tar kedua asap cair yang dihasilkan tidak dilakukan, namun keberadaan tar yang memiliki warna yang gelap dan berat molekul yang tinggi sehingga dapat mempengaruhi penampakan luar asap cair. Selain itu, adanya perbedaan metode produksi yang digunakan juga dapat mempengaruhi penampakan luar asap cair yang dihasilkan. Pada asap cair yang dihasilkan secara kondensasi langsung, masih terdapat komponen pengotor didalamnya se-hingga warnanya cenderung lebih gelap. Sedangkan pada asap cair menggunakan teknologi cyclone separator lebih berwarna kuning yang menandakan bahwa tidak adanya senyawa karbonil, tar dan benzo(a)pyrene. Jika dilihat dari penampakan asap cair yang dihasilkan yaitu berwarna kuning cerah, maka asap cair tersebut bisa digolong-kan ke asap cair grade 2 atau grade B yang dapat dimanfaatkan sebagai antimikroba (Kailaku et al., 2017).

\section{SIMPULAN}

Proses produksi asap cair grade C dengan teknologi cyclone separator secara signifikan mempengaruhi aliran neraca massa dan kandungan kimia penyusunnya. Penerapan teknologi cyclone separator mampu meningkatkan jumlah produksi asap cair dan menghasilkan arang lebih banyak jika dibandingkan dengan metode kondensasi langsung. Selain itu, berdasarkan analisis senyawa kimia, teknologi cyclone separator mampu meningkatkan jumlah gugus fungsi senyawa fenol dan alkoksi serta mengurangi hingga $100 \%$ gugus fungsi karbonil, ester dan asam yang didalamnya terdapat senyawa benzo(a)pyrene yang merupakan zat pengo-tor pada asap cair grade $\mathrm{C}$ yang dihasilkan. Namun demikian, penelitian selanjutnya disarankan untuk menganalisa senyawa kimia asap cair secara kuantitatif agar diketahui berapa banyak presentase kandungan dari setiap senyawa penyusun asap cair tersebut.

\section{DAFTAR PUSTAKA}

Bridgwater, A, Meier, Radlein, D. 1999. An overview of fast pyrolysis of biomass. Journal of Organic Geochemistry. 30(1), 1479-1493. https:/ / doi.org/10.1016/ S0146-6380(99)00120-5

Budaraga, I, Arnim, Yetti, M, Usman, B. 2016. Analysis of liquid smoke chemical components with GCMS from different raw materials variation production and pyrolysis temperature level. International Journal ChemTech Research. 9(6), 694708. https://www.researchgate.net/ publication/306209120_Analysis_of_liq uid_smoke_chemical_components_wit h_GC_MS_from_different_raw_materia ls_variation_production_and_pyrolysis _temperaturelevel

Budaraga, I, Arnim, Yetti, M, Usman, B. 2016. Liquid smoke production quality from raw materials variation and different pyrolysis temperature. International Journal Advanced Science Enginering and Information Technology. 6(3), 306-315. https://doi.org/10.18517/ijaseit.6.3.73 7

Budaraga, I, Arnim, Yetti, M, Usman, B. 2017. Chemical components analysis of cinnamon liquid smoke with GC-MS from various production of different purification method. International Journal ChemTech Research. 10(1), 12-26. https://www.researchgate.net/publica tion/315668476_Chemical_Component s_Analysis_of_Cinnamon_Liquid_Smo ke_with_GC_MS_from_Various_Produ ction_of_different_Purification_Method

Darmadji, P., Triyudiana, H. 2006. Proses pemurnian asap cair dan simulasi akumulasi kadar benzo(a)piren pada proses perendaman ikan. Agritech. 26(2), 94 - 103. http:/ /i-lib.ugm.ac.id/jurnal/ detail.php?dataId=3716

Direktorat Jenderal Perkebunan. 2019. Buku Statistik Perkebunan Indonesia untuk Tanaman Kelapa 2017-2019. Sekretariat Direktorat Jenderal Perkebunan. https: //drive.google.com/file/d/1rPFMCIR Y3KRrWofltc_KCcFR101ncrnI/view 
Fathussalam, M, Putranto, A. W., Argo B. D., Harianti A, Oktaviani A, Puspaningarum F. P., Putri, S. L. O. 2019. Rancang bangun mesin produksi asap cair dari tempurung kelapa berbasis teknologi cyclone-redistillation. Jurnal Ilmiah Rekayasa Pertanian dan Biosistem. 7(2), 148-156. https:// doi.org/10.29303/jrpb.v7i2.113

Hadanu, R, \& Daniel, A. 2016. Volatile compounds detected in coconut shell liquid smoke through pyrolysis at a fractioning temperature of $350-420^{\circ} \mathrm{C}$. Makara Journal of Science. 20(3), 95-100. 10.7454/mss.v20i3.6239

Hasanah, U, Bambang, S, Triyono, Chairil, A. 2012. The chemical composition and physical properties of the light and heavy tar resulted drom coconut shell pyrolysis. Journal Pure and Applied Chemistry Research. 1(1), 26-32. https:/ / doi.org /10.21776/ub.jpacr.2012.001.01.102

Kailaku, S, Syakir, M, Mulyawanti, I, Syah, A. 2016. Antimicrobial activity of coconut shell liquid smoke. IOP Conference Series: Materials Science and Engineering, 206. https://iopscience.iop.org/article/10.10 88/1757-899X/206/1/012050

Marinuc, M \& Rus, F. 2011. The effect of particle size and input velocity on cyclone separation process. Journal of Agricultural Food Engineering, 4(53), 117122. https://www.semanticscholar. org/paper/THE-EFFECT-OF-PARTIC LE-SIZE-AND-INPUT-VELOCITY-ONMarinuc/ac635e871b546d9b4f764e74f79a f5c524e4298a

Montazeri, N, Alexandra, C, Brian, H, Mary, B, Charles, A. 2013. Chemical characterization of commercial liquid smoke products. Journal Food Science \& Nutrition. 1(1), 102-115. https:/doi.org/10.1002/fs n3.9

Nasruddin. 2015. Karakteristik asap cair yang ditambahkan ekstrak aroma daun pandan wangi (Pandanus amaryllifolius Roxb.).
Jurnal Dinamika Penelitian Industri, 26(1), 19-31. https:/doi.org/10.28959/jdpi.v2 6 i1.698

Nikhil, S. 2015. A Review on gas solid cyclone separator parametric analysis. International Journal for Sciencetific Research $\mathcal{E}$ Development. 3(4), 1204-1208. http://ijsrd. com/Article.php?manuscript=IJSRDV3I4 0743

Putranto, A. W., Oktaviani, A., Puspaningarum, F. P. \& Sukardi. 2020. Coconut shell-liquid smoke production based on the redistillation-filtration technology and its characterisation. IOP Conference Series: Earth and Environmental Science. 475. https://iopscience.iop.org/article/ 10.1088/1755-1315/475/1/012039

Sisko, I., Zotos, A., Melidau, S., Tsikritzi, R. 2007. The effect of liquid smoking of fillet of trout (Salmo gairdherii) on sensory microbiological and chemical change during chilled storage. Food Chem. 101(2), 458-464. https://doi.org/10.1016/j.food chem.2006.02.002

Taiwo, M, Mohammed, A, James, B. 2016. Design and analysis of cyclone dust separator. Journal of Engineering Research. 5(4), 130-134. http:// www.ajer.org/ papers/v5(04)/O050401300134.pdf

Wagiman, F, Arik, A, Witjaksono. 2014. Activity of coconut-shell liquid-smoke as an insecticide on the rice brown planthopper (Nilaparvata lugens). Journal of Biological and Agricultural Science. 9(9), 293-296. http:/ / connection.ebscohost .com/c/articles/98738747/activity-coco nut-shell-liquid-smoke-as-insecticiderice-brown-planthopper-nilaparvatalugens

Yatagai, M. 2002. Utilization of charcoal and wood vinegar in japan. The University of Tokyo: Graduate School of Agricultural and Life Science. 